\title{
Radiocarbon Dates from the Pine Snake Site (41CE467), Cherokee County, Texas
}

Timothy K. Perttula

Heritage Research Center, Stephen F. Austin State University

Follow this and additional works at: https://scholarworks.sfasu.edu/ita

Part of the American Material Culture Commons, Archaeological Anthropology Commons, Environmental Studies Commons, Other American Studies Commons, Other Arts and Humanities Commons, Other History of Art, Architecture, and Archaeology Commons, and the United States History Commons

Tell us how this article helped you.

This Article is brought to you for free and open access by the Center for Regional Heritage Research at SFA ScholarWorks. It has been accepted for inclusion in Index of Texas Archaeology: Open Access Gray Literature from the Lone Star State by an authorized editor of SFA ScholarWorks. For more information, please contact cdsscholarworks@sfasu.edu. 


\section{Radiocarbon Dates from the Pine Snake Site (41CE467), Cherokee County, Texas}

Creative Commons License

(c) (i) (8)

This work is licensed under a Creative Commons Attribution-NonCommercial 4.0 International License 


\title{
Radiocarbon Dates from the Pine Snake Site (41CE467), Cherokee County, Texas
}

\author{
Timothy K. Perttula
}

\section{Introduction}

The Pine Snake site is a late $17^{\text {th }}$ to early $18^{\text {th }}$ century Caddo Indian archaeological site located on private land in the northwestern part of Cherokee County, Texas, in the valley of the westward-flowing Flat Creek, a tributary to the Neches River (Perttula et al. 2013). This is an area of the Pineywoods of East Texas that contains extensive numbers of Caddo archeological sites along all major and minor streams. Post-A.D. 1400 Frankston phase and post-A.D. 1650 Historic Caddo Allen phase sites, especially cemeteries dating to either phase, are particularly abundant in this part of East Texas. However, not many of these sites in the upper Neches River basin have had radiocarbon assays obtained from charred plant remains in feature contexts, and consequently the absolute age of most of these ancestral Caddo components and phases are not well or definitively established. Fortunately, charred Carya sp. nutshells are abundant in feature contexts in habitation deposits at the Pine Snake site, and samples of these remains have been submitted to DirectAMS (Seattle, Washington) for radiocarbon dating.

\section{Radiocarbon Samples and Calibrated Dates}

Shovel testing across the Pine Snake site (Figure 1) and the subsequent excavation of $5+1 \mathrm{x} 1$ $\mathrm{m}$ units (Figure 2) in and around a discovered hearth feature (Feature 1) and its associated very dark grayish-sediments led to the recovery of dateable samples of charred Carya sp. nutshells from 20-30 cm bs and $30-35 \mathrm{~cm}$ bs in Units 781, 783, and 785 (Table 1). The Feature 1 hearth basin extends from 31-48 $\mathrm{cm}$ bs in its center, and the charred plant remains sampled for radiocarbon dating are associated with the hearth deposits.

Table 1. Radiocarbon dates from the Pine Snake site (41CE467).

\begin{tabular}{lllll}
\hline DirectAMS \# & Unit & cm bs & $\begin{array}{l}\text { Conventional age, 1 } \\
\text { sigma, B.P. }\end{array}$ & $\begin{array}{l}\text { Calibrated age, } \\
2 \text { sigma, B.P. }\end{array}$ \\
\hline D-AMS 014250 & 781 & $20-30$ & $260-212$ & $281-307$ \\
D-AMS 014251 & 785 & $30-35$ & $276-226$ & $283-311$ \\
D-AMS 014225 & 783 & $20-30$ & $278-222$ & $282-315$ \\
\hline
\end{tabular}

The radiocarbon analyses discussed in this article were done by DirectAMS of Seattle, Washington. The radiocarbon ages obtained on these samples (see Table 1) have been calibrated to 2 sigma, years B.P., using IntCal13 (Reimer et al. 2013).

The conventional or corrected radiocarbon age of the three samples range from 278-212 years B.P., or A.D. 1672-1738. The conventional ages of the three samples overlap in age between 260-222 years B.P., or A.D. 1690-1728 (see Table 1). The two sigma calibrated age of the three radiocarbon samples from the Pine Snake site range from A.D. 1630-1678, overlap between A.D. 1631-1670, with calibrated median ages ranging from A.D. 1655-1664. The cumulative summed calibrated age ranges of the three dates are shown in Figure 3. 


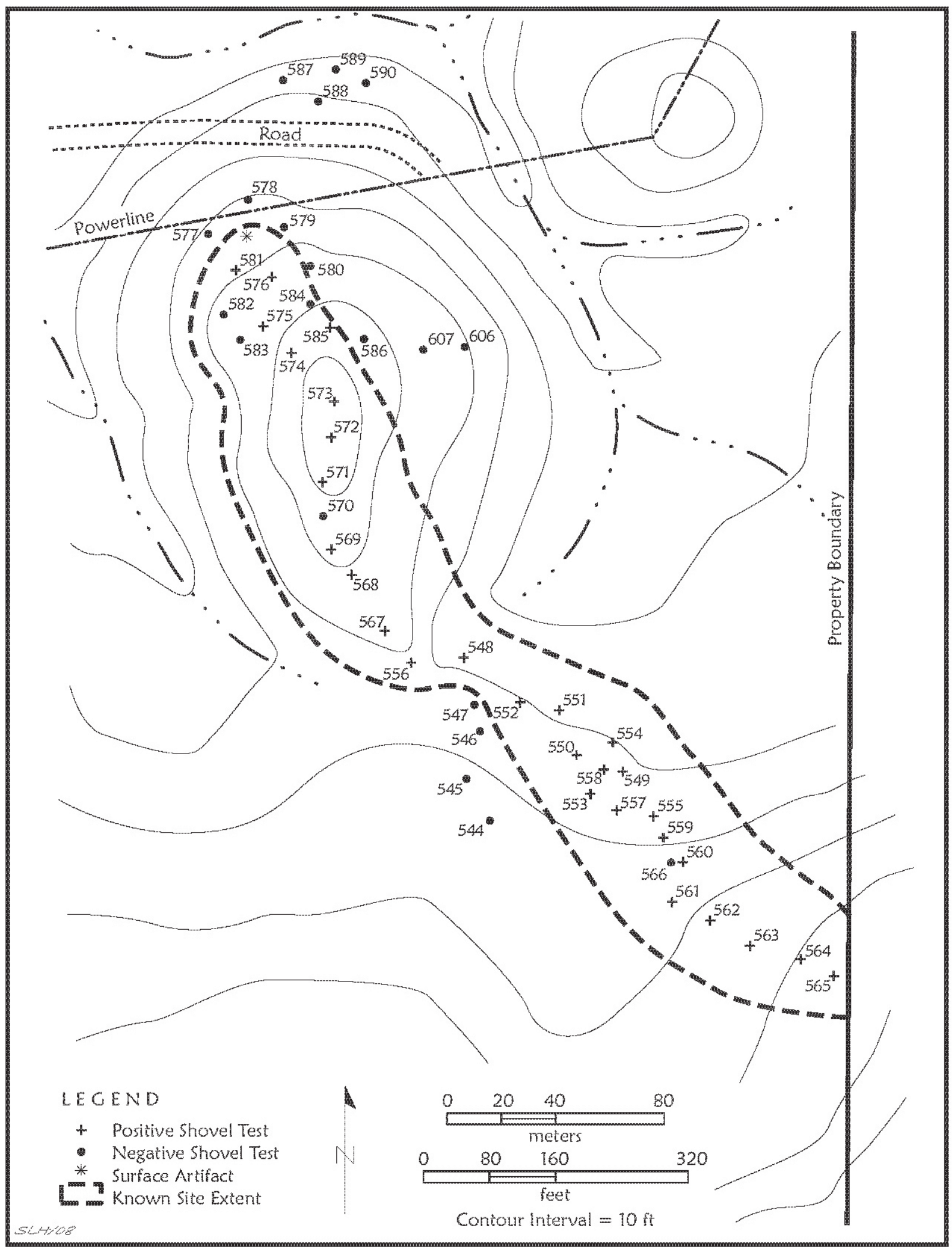

Figure 1. Map of the Pine Snake site. 


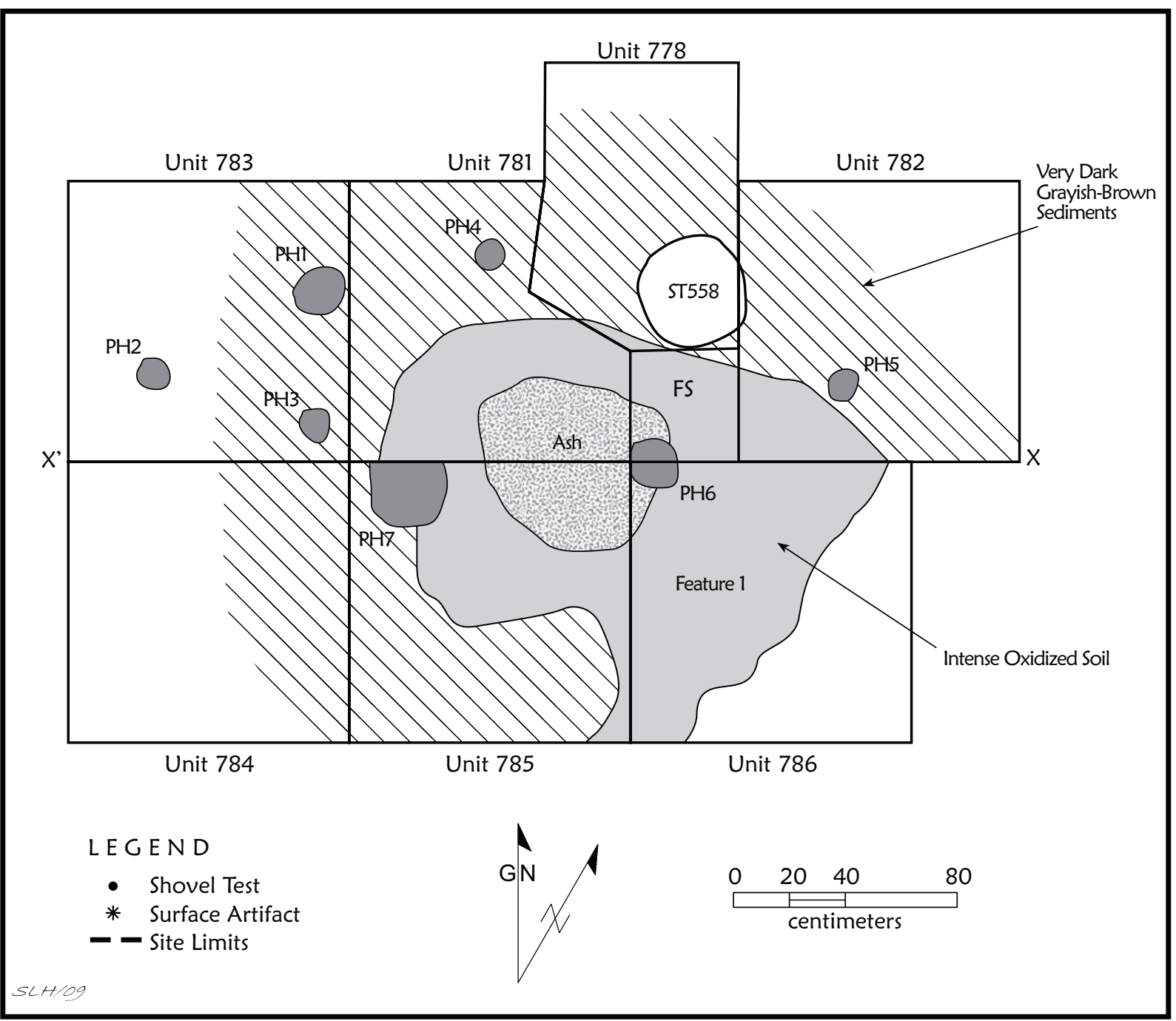

Figure 2. Plan of excavations in and around Feature 1 in the southern part of the Pine Snake site.

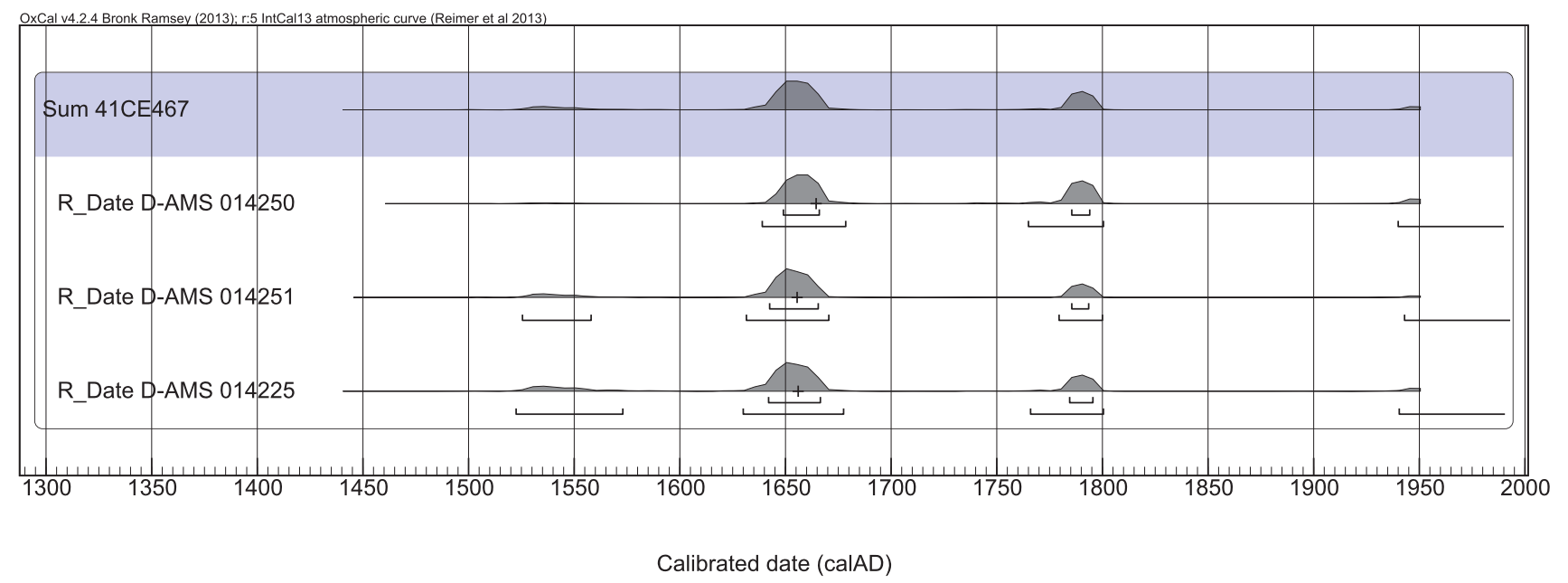

Figure 3. Cumulative summed probabilities of the three calibrated radiocarbon dates from the Pine Snake site. Figure provided by Robert Z. Selden, Jr. 


\section{Summary and Conclusions}

The Pine Snake site (41CE467) is an Allen phase Caddo habitation site in the Flat Creek valley, a westward-flowing tributary to the Neches River. Test excavations in the habitation deposits recovered charred Carya sp. nutshells in association with organically-stained sediments and a hearth feature. Three samples of nutshells from different proveniences in and immediately proximal to the hearth were submitted for radiocarbon analysis to more definitively establish the age of the Allen phase component at the site.

The radiocarbon results indicate that the charred nutshells from the Pine Snake site have conventional or corrected radiocarbon ages that range from 278-212 years B.P., or A.D. 1672-1738; they overlap in age between 260-222 years B.P., or A.D. 1690-1728. The two sigma calibrated age of the three radiocarbon samples from the site range from A.D. 1630-1678, overlap between A.D. 1631-1670, and have calibrated median age ranges between A.D. 1655-1664. The calibrated radiocarbon ages indicate that the habitation deposits in this one area of the Pine Snake site date to the early years of the Allen phase, at least a generation before any sustained contact between Caddo peoples and European explorers and traders.

\section{Acknowledgments}

Sandy Hannum prepared Figures 1 and 2 in this article, and Robert Z. Selden, Jr. provided Figure 3..

\section{References Cited}

Perttula, T. K., B. Nelson, and M. Walters, with a contribution by J. Feathers

2013 Archaeological Investigations at the Pine Snake Site, an Allen Phase Settlement on Flat Creek in Northwestern Cherokee County, Texas. Journal of Northeast Texas Archaeology 40:1-18.

Reimer, P. J., E. Bard, A. Bayliss, J. W. Beck, P. G. Blackwell, C. Bronk Ramsey, C. E. Buck, H. Cheng, R. L. Edwards, M. Friedrich, P. M. Grootes, T. P. Guilderson, H. Haflidason, I. Hajdas, C. Hatte, T. J. Heaton, D. L. Hoffman, A. G. Hogg, K. A. Hughen, K. F. Kaiser, B. Kromer, S. W. Manning, M. Niu, R. W. Reimer, D. A. Richards, E. M. Scitt, J. R. Southon, R. A. Staff, C. S. M. Turney, and J. van der Plicht

2013 IntCal13 and Marine13 Radiocarbon Age Calibration Curves 0-50,000 Years Cal BP. Radiocarbon 55(4):1869-1887. 